\title{
Pay Satisfaction and Role Ambiguity as Predictors of Job Burnout Among Osun State Civil Servants, Nigeria
}

\author{
Adeboye T. Ayinde PhD \\ Aderemi Obawole \\ Department of Psychology, Obafemi Awolowo University, Ile-Ife, Nigeria
}

URL:http://dx.doi.org/10.19044/esj.2019.v15n8p41

\begin{abstract}
The study assessed the levels of Job burnout and examined the extent to which pay satisfaction predicted job burnout among Osun State civil servants. It also investigated the extent to which role ambiguity predicted job burnout and determined whether there is a joint prediction of pay satisfaction and role ambiguity on job burnout. These were with a view to understanding the factors that predict job burnout among Osun State civil servants.

The study adopted the descriptive survey design. Primary data were collected through the administration of questionnaire on a sample of the study population. The study adopted multi-stage sampling technique. Purposive sampling technique was used to select eight ministries and stratified sampling technique was used to select 354 respondents comprising 214 males and 140 females with mean age of 43.39 years and standard deviation of 9.09. Three standardized psychological instruments namely: Pay Satisfaction Questionnaire (PSQ), Role Ambiguity Scale and Maslach Burnout Inventory (MBI) were used to collect the data for the study. The data generated was subjected to linear and multiple regression analyses.

The results revealed that civil servants exhibited a moderate level of job burnout (44.70\%). The results also showed that pay satisfaction significantly predicted job burnout among civil servants $(\beta=0.21, \mathrm{t}=3.53, P<.05)$. The results further revealed that role ambiguity significantly predicted job burnout among the respondents $(\beta=0.71, \mathrm{t}=8.37, P<.05)$. Finally, the results indicated that pay satisfaction and role ambiguity jointly predicted job burnout among civil servants $(\beta=28.13, \mathrm{t}=9.39, P<.05)$.

The study concluded that job burnout was moderate among Osun State civil servants, while pay satisfaction and role ambiguity independently and jointly predicted job burnout among respondents.
\end{abstract}


Keywords: Job Burnout, Pay Satisfaction, Role Ambiguity, Civil Servants, Osun State

\section{Introduction \\ Background to the Study}

Burnout is a syndrome characterized by emotional exhaustion which usually occurs among workers as a result of prolonged stress. Freudenberger (1974) became the first researcher to identify burnout from his study on extreme psychological strain which human service workers experience. Maslach and Jackson (1981) conceptualized burnout as having three components which are: emotional exhaustion, depersonalization, and reduced personal accomplishment. Emotional exhaustion is the key component of burnout and the most obvious manifestation of this syndrome. Depersonalization is the negative attitude towards and a dehumanizing treatment of one's clients in the work place, while reduced personal accomplishment is characterized by a tendency to negatively appraise one's behaviour and performance in one's work.

Work environment could become unpleasant due to the fact that inability of workers to resolve their domestic issues do sometimes override their thinking mentality. Thus, employees come to work when they get satisfied, especially when the need for food has been taken care of and other pressing needs are met. Job burnout has the potential of creating multiplier effects.For instance, in an organisation where the work schedule is in phases and is handled by different personnel, any work left undone by a demoralised worker will affect the work performance of other interconnected workers. This may happen on a continuous basis and it has a grave consequence for any organization.

Meanwhile, the symptoms of job burnout seem to be prevalent among different categories of workers in the public sector nowadays and this may not be unconnected with the current work conditions and prevailing economic environment. It is no longer a hidden fact that many civil servants in Nigeria are not well paid anymore especially in Osun State and this development tends to make these workers feel bored and lose interest in their work. Nagar (2012) opines that an employee who experiences high level of stress may not be able to perform effectively in his/her job. Poor service delivery might even lead to incompetence and high level of inferiority complex.

Employees get paid in return for their work in the organization and it has been found that they feel either positively or negatively about their pay (Williams, McDaniel and Nguyen,2006).However, in recent times, payment of salaries has been irregular in many states of this country, Osun State not excluded. Therefore, there is tendency for an employee to feel dissatisfied about his/her pay which could in turn affect the state of emotion of such 
employee. Also, dissatisfaction over pay might serve as precursor to job burnout. Pay satisfaction has been selected as the major independent variable for this study, because of the observation of partial and irregular payment of civil servants in Osun State.

Role ambiguity, on the other hand is the lack of clear information about job responsibilities and expectations, which is required for adequate performance of a role (Kahn, Wolfe, Quinn, and Snoek, 1964).It has equally been identified that role stress is of growing concern because of its significant implications for the psychological well-being of employees in an organisation mal-operation, (Worlu, Olokundun, Akinbode, Augusta, and Inelo, 2016). Organisations are networks of interrelated roles with role senders coming from various places or departments within the organization, and whenever the role ambiguity set in, the likelihood of job burnout is inevitable.

\section{Statement of the Problem}

Evaluating job burnout in Nigeria has become an important issue given the current pay situations among civil servants in Nigeria, particularly in Osun State. The working conditions under which civil servants operate are becoming increasingly demanding and the factors within their working environments seem to be deteriorating. Burnout as a work-related issue seems to be reeling its ugly head among civil servants, and it has the potential to disrupt employees’ performance, interpersonal relationship and well-being.

Job burnout may have received adequate attention in the literature where several studies have linked the variable with factors such as job satisfaction (Burisch, 2002; Kalliath and Morris, 2002), personality trait (Ayinde and Taiwo, 2014; Banerjee, 2015), turnover intention (Karatepe and Karatepe, 2010), and so on. However, many of the studies have not directly paired job burnout with employees' monthly emolument. Also, the influence of sociodemographic factors such as age, gender, etc., on this concept has been studied (Okwaraji and Aguwa, 2014), yet, there is paucity of studies in this area that considered the dynamic interaction of pay satisfaction and job burnout among Osun State civil servants, hence, this study.

\section{Review of Relevant Theories \\ Transactional Model of Stress}

Transactional model of stress was propounded by Lazarus and Folkman (1984). The theory emphasizes the on-going interaction between the person and the environment. As such, stress is not located in the person or the environment, but in the relationship between the environment, individuals' appraisals of the environment, and on-going attempts to cope with issues that arise. The theory encompasses a number of themes that capture the transactional nature of stress and the processes that best express the nature of 
that transaction. These themes include the following: Stress is a product of the transaction between the individual and the environment; the authority and power of the transaction lies in the process of appraisal that binds the person and the environment and it is this "relational meaning" (Lazarus, 2001) that the person constructs from the transaction and that lies at the heart of the stress process and there are two types of appraisal: primary and secondary. It is through these appraisals that the focus is shifted to what people think and do in a stressful encounter, representing a process-oriented approach.

As noted above, the model describes two stages of cognitive appraisal. First, primary appraisal involves appraisal of potential stressors as threatening and posing some kind of threat to the individual. This primary appraisal is where the person acknowledges that there is something at stake (Lazarus, 2001). This idea is where and when the person asks, "do I have a goal at stake?or are any on my core values engaged or threatened?" Lazarus identifies three types of primary appraisals: harm/loss - something that has already occurred, threat - the possibility of some harm in the future, and challenge where the person engages with the demand. Indeed, the situation may be perceived as challenging. Then, secondary appraisal involves the evaluation of coping resources and alternative responses. If an individual perceives that a situation is threatening, but that he or she has the ability to cope with it, then strain is not experienced. Secondary appraisal is where the focus turns to "what can be done about it?”.Here, the person evaluates the availability of coping resources (Lazarus, 2001). Coping has been defined as "the thoughts and behaviours used to manage the external and internal demands of situations that are appraised as stressful" and also shapes emotional responses (Folkman and Moskowitz, 2004). Two types of coping were identified: problem-focused (where focus is on managing the encounter), and emotion-focused (where the focus is on regulating the emotion) coping. Folkman and Moskowitz (2004) describe the above classification of coping strategies (problem-focused and emotion-focused) as a "broad brush approach". Since then, researchers have taken the opportunity to consider a range of ways of classifying coping strategies, expanding the original work to include, for example, strategies which include meaning-centred coping and relationship-social coping (Folkman, 2011). While no consensus has yet been reached as to the number of coping categories, researchers do agree that no category should be regarded as inherently better than another, because each needs to be considered within the context of a stressful encounter and how that encounter is appraised.

The theory offered a good explanation and view on the source of Job burnout in workers. It sees it in terms of appraisal and coping from the individual or some other element of the work environment.This transactional model posits that stress and related concepts (i.e. burnout) at work results from high effort spent in combination with low rewards obtained. It provides 
different perspectives to the view of the individual employee in perceiving Job burnout in the workplace.

\section{Review of Empirical Studies \\ Pay Satisfaction and Job Burnout}

Regarding both majority of findings about explaining variance in pay satisfaction and focusing them on determining the effect of Pay satisfaction on outcome variables, there are few empirical researches. Pay satisfaction is a universal relevant variable and it is known to be a motivating factor especially in this part of the world where millions of people are still trying to solve the physiological need, mostly in the area of survival. Adeyemi, Aina, and Olanipekun, (2006) reported that Nigerians are faced with problems emerging from low pay, job insecurity, long-hours culture, and gender inequality regarding job opportunities for women, and stressful situations at work. However, there is tendency for job burnout to in turn occur whenever an employee is not satisfied with his/her pay.

Banerjee (2015) concluded that some components of job satisfaction, mainly job content and promotion, could predict levels of burnout. According to LePine, Erez, and Johnson (2002), it is proclaimed that an employee who is not satisfied with his or her pay will tend to feel exhausted emotionally at work, and spend much of his/her time on the way out and would be engaged in contemplation,since he/she believes that the pay is not enough to handle the basic needs. In fact, employees who are satisfied and committed are more likely to attend work, stay with an organisation, be punctual to work, and perform well than employees who are not satisfied (Balogun and Olowodunoye, 2012). Smith, Organ, and Near (1983), found that pay satisfaction can result in important employee behaviour and feelings such as absenteeism, turnover, union voting and extra role. Furthermore, considerable amount of researches have noted that the more favourable the employee's satisfaction with the work place, the less the emotional exhaustion on the employee (Mcnight, Phillips and Hardgrave; 2009). Lee and Ashforth (1996) also found that job satisfaction correlates comparatively highly with all the three burnout dimensions where emotional exhaustion is the most important dimension.

\section{Role Ambiguity and Job Burnout}

Beauchamp, Bray, Eys and Carron (2004), in their study, present role ambiguity in four subtitles as follows: (a) the lack of clear identification of individuals' roles; (b) the lack of determination of responsibilities in line with the roles; (c) behaviour ambiguity related to roles of an individual; (d) not telling the unfulfilled responsibilities, which are required by the role of the individual, to employees. According to Katz and Kahn (1970), the two types 
of organizational tensions most highlighted in the literature are role conflict and role ambiguity, whereby the current study focuses on the ambiguity which can originate from the presence of organizational, personal and interpersonal factors, which can in turn affect the emotions and perceptions of employees while fulfilling their responsibilities. Piko (2006) suggested that the job burnout is detrimental to employee health, career progress and organizational effectiveness. Literature of role stress implies that role ambiguity and role conflict reduce the job satisfaction. It has been found that role ambiguity and role conflict lower performance and satisfaction among employees, especially the sales representatives (Singh, 1998; Fry, Charles, Parasuraman and Margaret, 1986). According to Chang and Hancock (2003), Job satisfaction is significantly negatively correlated with role ambiguity and role stress but no significant correlation between role overload and job satisfaction among nursing graduates. It has been indicated that discrepancy between the way the employees describe the kind of service orientation they think the employer should have and the way they describe upper management's service orientation is highly related to the way employees experience their work (Shahbaz and Ghafoor, 2015). Therefore, the larger the discrepancy, the more the role ambiguity and role conflict of employee. Karatepe, Yavas, Babakus and Avci (2006) argued that role stress has stronger effects on job satisfaction for certain types of personnel than others. This claim supports the finding of Babin and Boles (1998). Cooper and Payne (1978) have identified intrinsic job factors (e.g., poor working conditions and work overload), role in organizations (e.g., role conflict and role ambiguity), career development (e.g., lack of growth opportunities and job security), poor relationships at work, and organizational culture (e.g., politics in organization and lack of participation in decision making) as organizational stressors. Comparable job stressors have also been identified by Matteson and Ivancevich (1987) and all these stressors have a significant impact on both physical and emotional health and the health of the organization (International Labour Office, 1993). Reviews of the burnout literature have suggested that social workers are more likely to feel burnt out when they perceive higher levels of role stress (Hansung and Madeleine, 2008 1995). Cordes and Dougherty (1993) explain that role stress is directly related to emotional exhaustion which is the key aspect of job burnout. Over the years, studies have shown that an employee's level of emotional exhaustion is greatly affected by the nature and intensity of stress in the organisation. They further explain that an employee who is experiencing higher levels of emotional exhaustion is more likely to have depersonalized attitudes towards his or her clients and lack of personal accomplishment at work. Role stress has also been associated with turnover intention among human service employees (Mor Barak, Nissly and Levin; 2001). Therefore, it is expected that role stress, which is characterized as high levels of role 
ambiguity, role conflict, and role overload, is positively associated with burnout as well as with turnover intention among employees rendering human services. Kahn et al. (1964) have developed a theory of role dynamics which sees stress resulting from unclear or vague expectations and conflicting or incompatible expectations. Expectations which are unclear or vague may cause role ambiguity and this can in turn lead to job burnout. In this study, the extent to which role ambiguity would predicts job burnout exhibition in OsunState civil service of Nigeria would be examined.

\section{Methodology}

\section{Research Design}

The study adopted a descriptive survey design. Therefore, primary data is employed in this study. This research design is considered appropriate because it helped to establish a pattern of interaction between the variables of interest and provided numeric description of the sample of the population. The independent variables are pay satisfaction and role ambiguity, while the dependent variable is job burnout.

\section{Study Population}

The population for this study consisted of Osun State civil servants. This population represented secretariat members of staff of the state Ministries in the state capital (Osogbo). Report of the Accountant-General,Osun State (December, 2015) shows that there are twelve ministries in the state: Ministry of Education, Science \& Technology; Ministry of Health; Ministry of Agriculture, Food Security \& Youth Engagement; Ministry of Information \& Strategy; Ministry of Environment \& Sanitation; Ministry of Works \& Transport; Ministry of Commerce, Cooperative \& Empowerment; Ministry of Lands, Physical Planning \& Urban Development; Ministry of Justice; Ministry of Finance, Economic Planning \& Budget; Ministry of Local Government \& Chieftaincy Affairs; and Ministry of Human Resources \& Capacity Building. The approximate population size of the ministries is 11,000.

\section{Sample and Sampling Techniques}

The study adopted multi-stage sampling technique in the process of the selection and collection of data. Firstly, the purposive sampling technique is used in the selection of the eight ministries, which are: Ministry of Education, Science and Technology; Ministry of Health; Ministry of Agriculture, Food Security and Youth Engagement; Ministry of Finance, Economic Planning and Budget; Ministry of Environment and Sanitation; Ministry of Works and Transport; Ministry of Commerce, Cooperative and Empowerment and Ministry of Justice; all in Osun State, making a total number of 9248 staffs in the selected ministries. The selection is based on the criteria that the 
establishment is the civil service sector having a relatively large number of workers.

The sample size for this study was determined by the application of Taro Yemen's formula. Therefore, a sample size of 383 was arrived at as the minimum, but an attrition rate of $10 \%$ was added to make 421 in order to increase the strength of the study. At the second stage, stratified sampling was employed to select the participants, using the classification of ministries as the basis for stratification.

\section{Participants}

Four hundred and twenty one (421) copies of questionnaire were administered on the participants in the selected ministries proportionately to their size, however, three hundred and fifty-four (354) employees (civil servants) in the eight selected Ministries (Osun State civil service) responded to the research questionnaire. Participants comprise males and females, singles, married and divorced with mean age of 43.39 years and 9.09 as standard deviation, and from grade level one staff to senior staff members ( $G L$ $01-G L 17)$.

\section{Research Instrument}

Pay Satisfaction Questionnaire (PSQ): Pay Satisfaction Questionnaire was developed by Heneman and Schwab in 1985. PSQ consists of four dimensions and each reflects a relatively distinct (although perhaps related) aspect of pay with 18 itemsacross the four dimensions (pay level, benefits, pay raise, and pay structure/administration). The pay level which is the first dimension contains 4 items, the second dimension (benefits) contains 4 items,the third dimension (pay raise) also contains 4 items, while the fourth dimension (pay structure/administration) contains 6 items. The mean score was reported as 31.57 and the standard deviation of 8.22, while the coefficient alpha reliability reported for the overall scale was .91.

Role Ambiguity Scale: Role Ambiguity Scale is one out of the two dimensions of Role Stress Scale which was designed by Rizzo, House and Lirtman (1970). Role Stress Scale was used to measure the role stress of workers of several occupations and consists of two dimensions, one of which is applicable to this study; which measures role ambiguity. This subscale (Role Ambiguity) was adapted out of the Role Stress scale and it contains 15 items. Rizzo et al. (1970) modified the scale of role ambiguity and 12 items were reported to adequately measure role ambiguity. It was scored on a 4-point scale ranging from Strongly Disagree (1) to Strongly Agree (4). The subscale scores in a positive direction with higher scores indicating higher levels of stress. The scale has been the most widely used by researchers studying Role ambiguity (Jackson and Schuler, 1985). Tubre and Collins (2000) also reported that up 
to $85 \%$ of researchers studying role stress have used the scale. According to Schuler, Aldag and Brief (1977), this scale has been shown to have sufficient reliability and construct validity to warrant continued use.The mean score was reported as 31.89 and a standard deviation of 5.39, while the Cronbach alpha coefficient for the modified scale has been reported as .78.

Maslach Burnout Inventory (MBI): Maslach Burnout Inventory (Maslach, Jackson, and Leiter; 1981). The MBI was specifically designed to assess burnout among employees in workplace and has been the most widely used instrument in the literature (Maslach, Jackson and Leiter; 1996). The scale assesses three distinct aspects of burnout syndrome: emotional exhaustion, depersonalization, and personal accomplishment. The Emotional Exhaustion (EE) subscale assesses feelings of being emotionally drained and overextended by one's work. The Depersonalization (DP) subscale assesses cynical and impersonal attitudes towards clients. The Personal Accomplishment (PA) subscale assesses feelings of competence and achievement in one's work.The Maslach Burnout Inventory (MBI) is a selfreport questionnaire made up of 22 items. It was administered on the participants to measure their job burnout, and the participants rated the frequency of feelings related to each subscale using a 4-point scale ranging from 1 = Strongly Disagree to $4=$ Strongly Agree.Many studies had substantiated the validity and reliability of the MBI (Leiter, 1993). Ubangha (1997) also validated this scale and successfully used it in a study among secondary school teachers in Cross River State of Nigeria. The mean score was reported as 53.63 and the standard deviation as 9.34, while the Cronbach's alpha reported was 0.86 .

\section{Results}

Research Question One: What is the level of burnout among Osun State civil servants?

The respondents' score of job burnout ranges from $0-75$ andthe categories were gotten by the statistics of one standard deviation (9.09) above or below the mean $(53.79) \rightarrow($ Mean $\pm 1 \mathrm{SD})$, which was used to categorize respondents into groups according to their score on the job burnout scale.

Table 1: Respondents' Level of Job Burnout

F r e q u e n c y $\quad$ Percentage $\mathrm{S}$ c

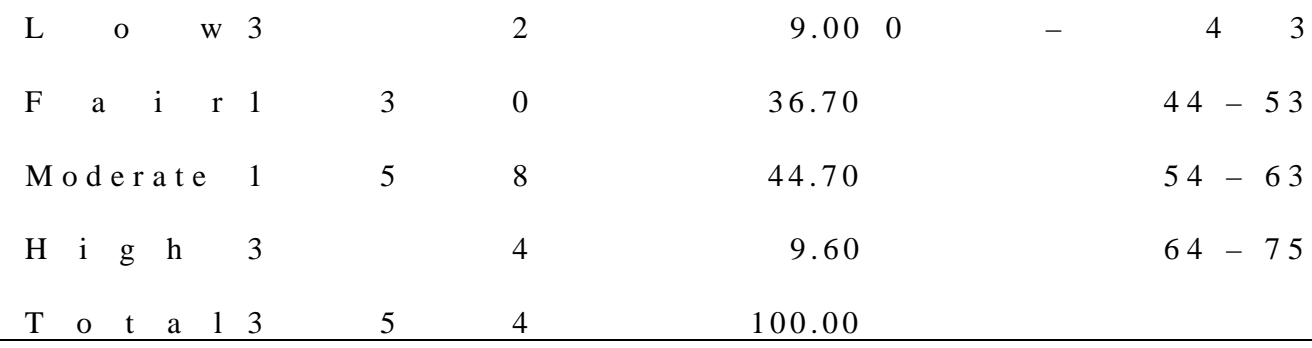


As presented in Table 1, the level of job burnout has been categorized into low, fair, moderate and high, using the items that suit each subcategory.It is deduced from the table that the level of job burnout among this respondents is moderate because highest number of respondents (158) had moderate scores which ranges between 54 and 63 .

Hypothesis One: Pay satisfaction will significantly predict Job burnout of employees in Osun State civil service.

Linear regression analysis to test the hypothesis at 0.05 level of significance.

Table 2a: Model Summary of the Linear Regression of the Variable

\begin{tabular}{|c|c|c|c|c|c|c|c|}
\hline Model & $\mathbf{R}$ & R Square & Adjusted R Square & Std, Error of the Estimate & R Square Change & F Change & Sig. F Change \\
\hline 1 & $0.185^{\mathrm{a}}$ & $\begin{array}{lll}0 & 3 & 4\end{array}$ & $\begin{array}{lll}0 & 3 & 1\end{array}$ & $\begin{array}{lll}1 & 9 & 5\end{array}$ & 0.034 & 12.456 & 0.0101 \\
\hline
\end{tabular}

Table 2b: Coefficients of the Model Summary of the Linear Regression

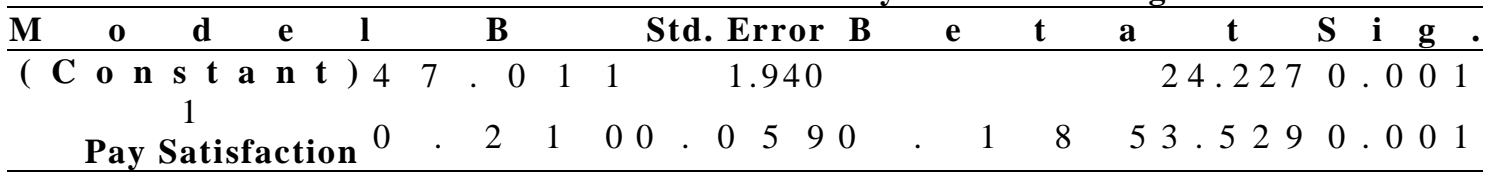

\section{Dependent Variable: Job Burnout}

As presented in Table 2, pay satisfaction accounted for $3.4 \%$ of the variance in job burnout $(\beta=0.210, t=3.529, P=0.001)$. This finding suggests that pay satisfaction significantly predicted job burnout of civil servants. Hence, the alternate hypothesis which states that pay satisfaction will significantly predict Job burnout of employees inOsun State civil service was accepted.

Hypothesis Two: Role ambiguity will significantly predict job burnout of employees in Osun State civil service.

Linear regression analysis was used to test the hypothesis at 0.05 level of significance.

Table 3a: Model Summary of the Linear Regression of the Variable

\begin{tabular}{|c|c|c|c|c|c|c|c|}
\hline Model & $\mathbf{R}$ & R Square & Adjusted R Square & Std. Error of the Estimate & R Square Change & F Change & Sig. F Change \\
\hline 1 & $0.408^{a}$ & 0.166 & 164 & $\begin{array}{lll}5 & 4 & 3\end{array}$ & 0.166 & 70.142 & 0.001 \\
\hline
\end{tabular}

b.

Table 3b: Coefficients of the Model Summary of the Linear Regression

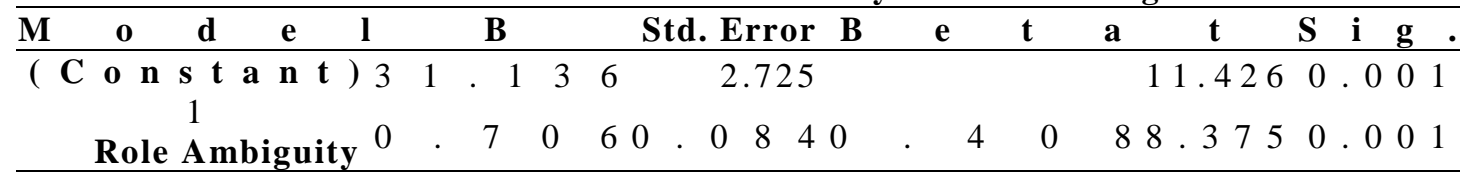




\section{Dependent Variable: Job Burnout}

As presented in Table 3, role ambiguity accounted for $16.6 \%$ of the variance in job burnout $(\beta=0.706, t=8.375, P=0.001)$. This finding suggests that role ambiguity significantly predicted job burnout of civil servants. Therefore, the alternate hypothesis which states that role ambiguity will significantly predict Job burnout of employees inOsunState civil service was accepted.

Hypothesis Three: Pay satisfaction and role ambiguity will jointly predict pay satisfaction and role ambiguity on job burnout of employees in Osun State civil service.

Multiple regression analysis was used to test the hypothesis at 0.05 level of significance.

Table 4a: Model Summary of the Multiple Regression of the Variables

\begin{tabular}{|c|c|c|c|c|c|c|c|}
\hline Model & $\mathbf{R}$ & R Square & Adjusted R Square & Stdd, Erroo of the Estimate & R Square Change & F Change & Sig. F Change \\
\hline 1 & $0.408^{\mathrm{a}}$ & 0.166 & 0.164 & $\begin{array}{lll}5 & 43\end{array}$ & 0.166 & 5.546 & 0.001 \\
\hline 2 & $0.423^{b}$ & 0.179 & 0.174 & $\begin{array}{lll}4 & 8 & 9\end{array}$ & 0.013 & 70.142 & 0.019 \\
\hline
\end{tabular}

1. Predictors: (Constant), Role Ambiguity

2. Predictors: (Constant), Role Ambiguity, Pay Satisfaction

Table 4b: Coefficients of the Model Summary

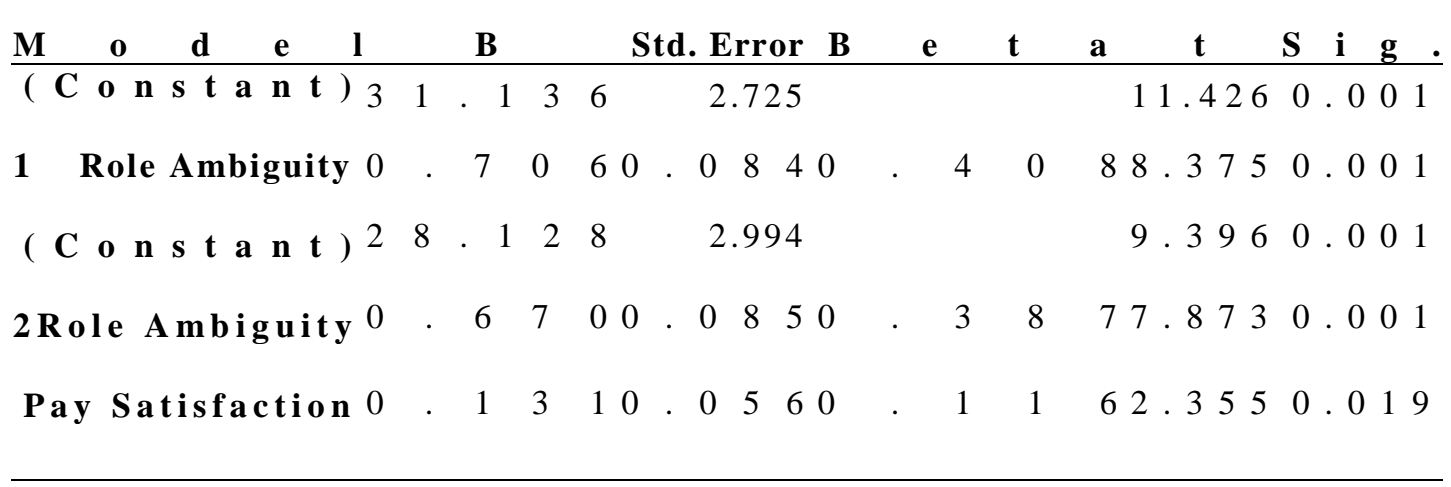

\section{Dependent Variable: Job Burnout}

As presented in Table 4, both pay satisfaction and role ambiguity explained $17.9 \%$ of the variance in job burnout $(\beta=28.128, \mathrm{t}=9.396, \mathrm{P}=$ $0.001)$. This finding suggests that both pay satisfaction and role ambiguity had a significant joint prediction on job burnout of civil servants.Thus, alternate hypothesis which states that there is a significant joint prediction of pay satisfaction and role ambiguity on job burnout of employees in Osun State civil servicewas accepted.

\section{Discussion}

The study contributes to knowledge on predictors of job burnout among Osun State civil servants whereby pay satisfaction and role ambiguity were considered. There appears to be a moderate level of exhibition of Job burnout 
in civil service from the general picture of the descriptive analysis. This is evident in the number of workers $(158 ; 44.7 \%)$ who exhibit moderate job burnout. 130 (36.7\%) workers exhibitfair job burnout, 34 (9.6\%) workers exhibit high job burnout, while only 32 (9.0\%) of total the respondents report low job burnout. This finding is in agreement with the result of Azeem,Nazir,Zaidi and Akhtar (2014) that reported the moderate levels of stress and job burnout among the nurses working in the private hospital. It also finds support in the work of Rebecca and Wendy (2007), who found out the moderate levels of job burnout among public hospital nurses.Thebasis forthis moderateexhibition of job burnoutmay notbe unconnectedwith thefallen enthusiasm and displeasure ofworkers towards work. This apathycould be based on workers'feelings towards the irregular and incomplete monthly emoluments.

With regards to the hypotheses formulated toguidethis study, the first hypothesis which states that pay satisfaction will significantly predict job burnout of employees in Osun State civil service revealed that there was a significant prediction of pay satisfaction on job burnout of Osun State civil servants. This is an indication that being dissatisfied on monthly remuneration as an employee could increase the level of job burnout of such employee, that is, the higher the civil servants get dissatisfied with their salary, the greater the possibility of exhibiting a higher level of burnout. This suggests that civil servants' exhibitions of job burnout are predicted byfeelings ofdissatisfaction on their pay. The finding of this study finds support in the work of Khamisa, Oldenburg, Peltzer and Ilic (2015) who found out thatburnout and job satisfaction demonstrate a relationship among nurses. The finding is also in line with the report of Ramin, Mahlaga and Mahmoud (2015) who deduced that burnout and job satisfaction are related to the nature of job and working conditions so that lack of reward and appropriate appreciating and the lack of organizational confidence lead to the creation of job burnout in school physical education teachers. The possible reason for this corroboration might not be unconnected with the nature of the job which involves rendering of services and not production. Also, feelings of dissatisfaction that the employees derive from their pay and reward could be considered as the plausible reason for the finding. Secondly, the findings revealed that there was significant prediction of role ambiguity on job burnout. This invariablymeans that job burnout amongcivil servants in Osun State is influenced bytheir role ambiguity in the work. It implies that the level of civil servants' job burnout interacts with the clear knowledge and understanding of their roles and duties at work. This is an indication that, lack of clear understanding of roles could increase the level of job burnout, that is, the higher a civil servant is uncertain about his/her role, the greater the possibility of exhibiting a higher level of job burnout. This finding finds support in the work of Maslach and Leiter (2008), 
who found relationship between workload and job burnout. Thefindingis also in agreement withthestudies of Hansung and Madeleine (2008), who reported that job autonomy interacted with role stress in predicting burnout of social workers. The finding is also corroborated by the finding of Azeem et al. (2014) who asserted that role ambiguity and other role related stressors are predictors of job burnout. Individuals who have unclear information on role are more likely to exhibit higher levels of job burnout. The plausible reason for these findings could be adduced to lack of orientation and proper training for civil servants and inability to learn through mentorship, unlike their counterparts in the private organizations.

Lastly, the finding of this study on the joint predictive ability ofpay satisfaction and role ambiguity on job burnout among Osun State civil servants which forms the basis for the third hypothesis revealed that both pay satisfaction and role ambiguity jointly predicted job burnout of the civil servants under study. This implies that as employees experience dissatisfaction on their monthly emoluments and unclear information on their duties, their tendency to exhibit burnout intensifies. This finding is corroborated by previous research. For example, a study that was conducted by Karimi, Omar, Alipour, and Karim (2014) showed that the role ambiguity and other role stress influenced occupational stress among nurses (employees). Also, Idris (2011) reported that employees' uncertainty and inadequate knowledge about their responsibilities and the goals of their organization intensify their level of stress. The plausible reason for these findings may not be unconnected with the fact that individuals' difference in terms of their acceptance of being satisfied combined with their knowledge about their roles and duties can influence their behaviour and emotional state in the workplace.

\section{Recommendations}

Steps like establishing a job burnout workshop should be taken to limit and curb job burnoutinthe civil servicesectorsof Nigeriawhere it appears that demoralized employeesarenot performing effectively in order to promote the productivity and effectiveness of the organization.Human resource managers, personnel managers, organizations and organizational/industrial psychologists should give adequate, suitable and full attention to job burnout, pay satisfaction and training of employees. Pay satisfaction and role ambiguity should not be overlooked in order to reduce the exhibition of job burnout and employers should find a way of rehabilitating the employees who exhibit high level of job burnout since it affects organizational effectiveness and efficiency.

More so, studies should be conducted to involve every category of workers in the civil service establishment. This mightgive more insight into the prediction of pay satisfaction and role ambiguity onjob burnout. The study 
should also be expanded to other establishment (public and private organizations) and also be carried out in all major regions of Nigeriatohaveabroaderviewofjob burnout in Nigeria setting which can then be compared with findings obtained from other countries and the western world. Moreover, dimensions job burnoutshouldbedefinedto see theeffectsof the independent variable (pay satisfaction \& role ambiguity) on them. In addition, some other factors like age, gender, religious beliefs, economic status, and education level should be included in further studies.

Finally, expanding the study to private establishments and comparing data could also give more insight into the prediction of pay satisfaction and role ambiguity on job burnout, as peoplegenerallyperceivegovernment jobsas easy and not requiring extra effort. The consideration of the numerated limitations of this study basically advises any researcher who wants to replicate this study to endeavour to use a large sample size from all public institutions in different parts of Nigeria and representative of their diverse population for further research.

\section{References:}

1. Adeyemi, A.Y., Ojo, S.O., Aina, O.O., Olanipekun, E.A., (2006). Empirical evidence of women under-representation in the construction industry in Nigeria.Women in Management Review.Vol.21 (7): 567-577.

2. Ayinde, A.T. \&Taiwo O.D. (2014) 'Big-Five Personality Traits as correlate of Employee's Perception of Job Burn-out among Workers of Ewekoro Cement Industry, Nigeria'.Journal of Emerging Trends in Economics and Management Sciences (JETEMS), vol. 5(6) 550 558. Manchester, UK.

3. Azeem, S.M., Nazir, N.A., Zaidi, Z.B., \&Akhtar, N. (2014).Role of stress and burnout among nurses in the private hospitals.Int $J$ Acad Res Bus Soc, Vol. 4:420e8.

4. Babin, B.J., \& Boles, J.S. (1996). The effects of perceived co-worker involvement and supervisor support on service provider role stress, performance and job satisfaction. Journal of Retailing. Vol. 72 (1), 57-75.

5. Balogun, A.G., \&Olowodunoye, S.A. (2012). Psychological factors as predictors of turnover intention among employees of postconsolidation banks in Nigeria. European Scientific Journal,Vol. 8(20): 81-95.

6. Banerjee, S. (2015).A Study of the relationship between job satisfaction and life satisfaction.International Journal of Business Quantitative Economic and Applied Management Research. Vol. 1(8): 30-41. 
7. Beauchamp, M. R., Bray, S. R., Eys, M. A., \& Carron, A. V. (2005). The Relationship between Role Ambiguity and Intention to Return the Following Season, Journal of Applied Sport Psychology,Vol. 17(3): 255-261

8. Bühler, K.E., \& Land, T. (2003). Burnout and Personality in Intensive Care: An Empirical Study. Hospital Topics, Vol. 81(4):5-12.

9. Burisch, M., (2002). A longitudinal study of burnout: the relative importance of dispositions and experiences. Work and Stress. Vol. 16: $1-17$.

10. Chang, E. \& Hancock, K. (2003). Role stress and role ambiguity in new nursing graduates in Australia. Nursing and Health Sciences. Vol. 5: 155-163.

11. Cooper, C.L. \& Payne, R. (1978). Stress at work, New York, John Wiley.

12. Cordes, C. L., \& Dougherty, T. W. (1993).A review and integration of research on job burnout.Academy of Management Review, 18, 621656.

13. Folkman, S. \& Moskowitz, J. T. (2004) 'Copping: Pitfalls and Promise' Annual Review of Psychology, 55, 745 -774

14. Freudenberger, H.J. (1974). "Staff burnout".Journal of Social Issues. Vol. 30: 159-165.

15. Fry, L., Charles, M., Parasuraman, A., \& Margaret, A.C. (1986). An analysis of alternative casual models of salesperson role perceptions and work related attitudes. Journal of Marketing Research. Vol. 23: 153-163.

16. Hansung, K. \& Madeleine, S. (2008). Burnout and Turnover Intention among Social Workers: Effect of Role Stress, Job Autonomy and Social Support, Administration in Social Work, Vol. 32 (3): 5 - 25.

17. Heneman, H.G. III, \& Schwab, D.P. (1985). Pay satisfaction: Its multidimensional nature and measurement. International Journal of Psychology. Vol. 20: 129-141.

18. Idris, M. K. (2011). Over Time Effects of Role Stress on Psychological Strain among Malaysian Public University Academics.International Journal of Business and Social Science, Vol. 2(9): $154-161$

19. International Labour Office.(1993). World Labor Report 1993. Geneva: International Labour Office.

20. Jackson, S., \& Schuler, R. (1985). A meta-analysis and conceptual critique of research on role ambiguity and role conflict in work settings. Organizational Behaviour and Human Decision Processes. Vol. 36, $16-78$. 
21. Kahn, R. L., Wolfe, D. M., Quinn, R. P., Snoek, J. D., \& Rosenthal, R. A. (1964).Occupational stress: Studies in role conflict and ambiguity. New York: Wiley.

22. Karatepe, O. M., \& Karatepe, T. (2010) Role Stress, Emotional Exhaustion, and Turnover Intentions: Does Organizational Tenure in Hotels Matter? Journal of Human Resources in Hospitality \& Tourism. Vol. 9(1): $1-16$.

23. Karatepe, O., Yavas, U., Babakus, E., \&Avci, T. (2006). Does gender moderate the effect of role stress in frontline service jobs? Journal of business research, Vol. 59 (10-11), 1087-1093.

24. Karimi, R., Omar, Z. B., Alipour, F., \&Karimi, Z. (2014).The Influence of Role Overload, Role Conflict and Role Ambiguity on Occupational Stress among Nurses in Selected Iranian Hospital.International Journal of Asian Social Science, 34-40.

25. Katz, D., \& Kahn, R. L. (1970).Psicologia social das organizações (2nd ed.). São Paulo: Atlas.

26. Khamisa, N., Oldenburg, B., Peltzer, K. \&llic, D. (2015). "Work Related Stress, Burnout, Job Satisfaction and General Health of Nurses". International Journal of Environmental Research and Public Health, 12(1): 652-666.

27. Lazarus, R. S. (2001). Conservation of resources theory (COR): Little more than words masquerading as a new theory. Applied Psychology: An International Review. Vol. 50: 381 - 391.

28. Lazarus, R. S., \& Folkman, S. (1984). Stress, appraisal, and coping. New York: Springer.

29. Lee, R. T., \& Ashforth, B. E. (1996). A meta-analytic examination of the correlates of the three dimensions of job burnout. Journal of Applied Psychology. Vol. 81 (2), 123 - 133.

30. Leiter, M. P. (1993). Burnout as a developmental process: Consideration of models. In W. B. Schaufeli, C. Maslach, \& T. Marek (Eds.), Professional burnout: Recent developments in theory and research (pp. 237-250). Washington, DC: Taylor \& Francis.

31. LePine, J. A., Erez, A., \& Johnson, D. E. (2000). The nature and dimensionality oforganisational citizenship behaviour: a critical review and a meta-analysis.Journal ofApplied Psychology, 87(1), 5265.

32. Maslach, C., \& Jackson, S. E. (1981).The measurement of experienced burnout.Journal of Occupational Behaviour. Vol. 2, 99 113.

33. Maslach, C., Jackson, S. E., \&Leiter, M. (1996).Maslach Burnout Inventory. Manual (3rd ed.). Palo Alto, CA: Consulting Psychologists Press. 
34. Maslach, C.\&Leiter, M.P. (2008).Early Predictors of Job Burnout and Engagement.Journal of Applied Psychology. Vol.93 (3): 498 - 512.

35. Matteson, M.T. \&Ivancevich, J.M. (1987). Controlling work stress: Effective human resource and management. San Francisco, CA: Jossey Bass.

36. McKnight, D. H., Phillips, B., \& Hardgrave, B. C. (2009). Which reduces IT turnover intention the most: Workplace characteristics or job characteristics?.Information\& Management, 46, 167174.

37. Mor Barak, M.E., Nissly, J.A., \& Levin, A. (2001). Antecedents to retention and turnover among child welfare, social work, and other human service employees: What can we learn from past research? A review and meta-analysis.Social Service Review, 75(4), 625-662.

38. Nagar, K. (2012). Organizational Commitment and Job Satisfaction among Teachers during times of Burnout. VIKALPA, 37(2), 43-60.

39. Osun State Annual Report, (unpublished) December, 2015 htt://osun.gov.ng/mds/ministries

40. Okwaraji, F. E., \&Aguwa, E. N. (2014).Burnout and psychological distress among nurses in a Nigerian tertiary health institution.African Health Sciences. Vol. 14(1): 237-245.

41. Piko, B. (2006). Burnout, role conflict, job satisfaction and psychosocial health among Hungarian health care staff: A questionnaire survey. International Journal of Nursing Studies. Vol. 43, 311-318.

42. Ramin, A., Mahlaga, F. and Mahmoud, V. (2015) 'The Relationship between Burnout and Job Satisfaction of Physical Education Teachers in Shabestar City Indian Journal of Fundamental and Applied Life $\begin{array}{lllll}\text { Sciences } & \text { Vol. } & 5 & \text { (S2), } & \text { pp. }\end{array}$ www.cibtech.org/sp.ed/jls/2015/02/jls.htm

43. Rebecca, S.S.\& Wendy, P.A. (2007).Determinants of burnout among public hospital nurses.Australian Journal of Advanced Nursing, Vol. 25(1): 8-16.

44. Rizzo, J. R., House, R. J., \& Lirtzman, S. I. (1970).Role conflict and ambiguity in complex organizations.Administrative Science Quarterly, 15, 150 - 163.

45. Schuler, R. S., Aldag, R. J., \& Brief, A. P. (1977). Role Conflict and Ambiguity: A Scale Analysis. Organizational Behaviour and Human Performance, Vol. 20(11): 1-128.

46. Shahbaz, W. \&Ghafoor, M.M. (2015).Role Stress and Job Satisfaction: A Case Study of Personnel of Water and Sanitation Agencies of Punjab, Pakistan. International Journal of management \& organizational studies, Vol. 4 (3): 2305 - 2600. 
47. Singh, J. (1998). Striking a balance in boundary-spanning positions: an investigation of some unconventional influences of role stressors and job characteristics on job outcomes of salespeople.J Mar Sci. vol. 62(3): 69-86.

48. Smith, C.A., Organ, D.W. and Near, J.P. (1983). Organizational citizenship behaviour: Its nature and antecedents. Journal of Applied Psychology, vol. 68, no. 4, pp. 653-663.

49. Tubre, T.C. \& Collins, J.M. (2000).A Meta-Analysis of the Relationships between Role Ambiguity, Role Conflict, and Job Performance.Journal of Management, Vol. 26, 155-169.

50. Ubangha (1997).Understanding Illness Behaviour, Death and Bereavement in Adulthood.The Counsellor, 16(1): 97-103.

51. Williams, M.L., McDaniel, M.A., Nguyen, N.T., (2006). A metaanalysis of the antecedents and consequences of pay level satisfaction.Journal of Applied Psychology. Vol. 91 (2): 392-413.

52. Worlu, R, Olokundun, M. , Akinbode, M. Augusta, A. and Inelo, F. (2016) 'Stress Arising from Work Roles and Impediments to Organizational Performance' Research Journal of Medical Sciences Vol. 10, No 1 PP 1 - 5. DOI: 10.3923/rjmsci.2016.1.5 